\title{
DRZEWA-POMNIKI PRZYRODY JAKO ELEMENT PRODUKTU TURYSTYKI KULTUROWEJ
}

\section{Wstęp}

Drzewa należą do trwałych nasadzeń, kształtujących krajobraz w ciągu wieków. Tworzą tożsamość i unikalny charakter określonych miejsc. Są dominującymi elementami przestrzennymi nie tylko pod względem wizualnym, estetycznym, ale też w zakresie oddziaływania klimatycznego i oczyszczającego środowisko. Wpływają na podnoszenie walorów architektury i tworzenie ładu przestrzennego, chronią uprawy, zasłaniają nieatrakcyjne miejsca, zapewniają prywatność i komfort. Na okazałe drzewa czeka się przez pokolenia, a ich strata w niektórych miejscach jest nieodwracalna (Szczepanowska, 2007; Wagner, 2003). Drzewa, oprócz walorów przyrodniczych, mają znaczenie kulturowe, społeczne i ekonomiczne. Obok pozytywnego wpływu na zdrowie fizyczne człowieka, istotne korzyści uzyskiwane z obecności roślinności, zwłaszcza drzew, dotyczą sfery psychicznej, a nawet duchowej. Studia psychologicznego oddziaływania zieleni potwierdzają korzystny wpływ drzew na zdrowie i dobre samopoczucia człowieka. Samo przebywanie w otoczeniu roślin działa na organizm ludzki uspokajająco. Stwierdzono również, iż widok natury ma działanie lecznicze - pomaga redukować stres i lęk - w przeciewieństwie do oglądania miejsc zabudowanych, powodujących uczucie smutku (Szczepanowska, 2007).

Decydując się na wyjazd zagraniczny czy krajowy, podróżni opierają swój wybór nie tylko na walorach przyrodniczych wybranego miejsca, ale również kulturowych. Sędziwe drzewa, o okazałych wymiarach, oraz związane z nimi tajemnicze historie, legendy i wierzenia stały się interesującym elementem krajobrazu, przyciągającym zwiedzających. Turystyka 
stwarza człowiekowi dogodne warunki do odbierania różnego rodzaju treści poznawczych. Drzewa, szczególnie cenne w wymiarze lokalnym i krajowym, a nawet europejskim, stanowią część naturalnego krajobrazu, mogą stać się również ciekawymi okazami w rozwoju turystyki kulturowej czy przyrodniczej. Szczególne okazy dendroflory mogą stanowić przyrodniczą wizytówkę miejscowości oraz być elementem jej promocji.

Celem artykułu jest przedstawienie możliwości wykorzystania bogactwa zawartego w dziedzictwie przyrodniczym, jakim są drzewa-pomniki przyrody, w kontekście kształtowania interesującej oferty turystyki kulturowej. W opracowaniu skoncentrowano się na związkach elementów przyrody i kultury oraz wybranych drzewach - okazach reprezentujących wartości i cechy, które mogą być potencjalnie wykorzystane jako elementy złożonego produktu turystycznego. Podkreślono również rolę mniej znanych pomników przyrody jako elementów środowiska naturalnego z ciekawym wątkiem kulturowym, które można wykorzystać do przygotowania niezwykle interesującej i odmiennej od innych oferty turystycznej.

\section{Drzewa-pomniki przyrody jako obiekty kulturowe}

Wpływ świata zwierząt i roślin na życie człowieka jest niezwykle silny. Sędziwe drzewa chroni się nie tylko ze względu na ich wartość przyrodnicza, ale również $\mathrm{w}$ związku $\mathrm{z}$ ich znaczeniem kulturowym - w wielu kręgach drzewa symbolizują miejsca przebywania różnorakich bóstw, stąd były i są przedmiotem czci i szacunku. Motywami ich ochrony są m.in. cele naukowe, genetyczne, krajobrazowe, ekologiczne, historyczne (zabytkowe, pamiątkowe), patriotyczne czy dydaktyczne (Grzywacz, 2011).

Pomniki przyrody, początkowo określane mianem „zabytków przyrody", są najstarszą formą ochrony tworów przyrody w Polsce (od XIX w.). Na ziemiach polskich podczas zaborów niektóre stare drzewa traktowano nie tylko jak pomniki przyrody, ale również jak obiekty zabytkowe, świadków dawnej świetności, elementy ojczystej przyrody, „pomoce dydaktyczne" w patriotycznej i państwowotwórczej edukacji społeczeństwa (Grzywacz, 2011).

Dzięki inwentaryzacjom zasobów przyrody, prowadzonym przed II wojną światową na terenie Polski przez przyrodników i leśników, wskazano ok. 4,5 tys. drzew, które zasługiwały wówczas na miano pomników przyrody. Jednakże dopiero w 1949 r. wprowadzono odpowiedni zapis w ówczesnej ustawie o ochronie przyrody, który umożliwił objęcie cennych drzew ochroną prawną (Ustawa, 1949). W efekcie liczba chronionych 
obiektów zaczęła rosnąć, tworząc do dziś rejestr ponad 36 tys. pomników przyrody (Ochrona Środowiska 2018, 2018). O zakwalifikowaniu drzewa do objęcia ochroną jako pomnika przyrody decydują względy wiekowe lub gabarytowe. Okaz powinien charakteryzować się unikatową "wartością przyrodnicza, naukową, kulturową, historyczną lub krajobrazową" (Rozporzadzenie, 2017; Ustawa, 2004).

Zapewnianie ochrony indywidualnym obiektom przyrodniczym jest integralną częścią prawnej ochrony całości zasobów przyrody ożywionej i nieożywionej. Poszczególne okazy powinny zatem posiadać cechy indywidualne, które wyróżniają je spośród innych tworów przyrody ożywionej - w Polsce najczęściej są to pokaźnych rozmiarów drzewa $(95,5 \%)$ (Pietrzak, 2011). Najczęściej ochroną obejmowane są okazałe dęby, lipy, buki i klony. Z najnowszych zestawień wynika, że najstarsze, najokazalsze pomniki przyrody to grupa 1641 drzew, które osiągnęły lub przekroczyły pierśnicowy obwód pnia równy $600 \mathrm{~cm}$, wśród nich jest 77 okazów o obwodzie równym $800 \mathrm{~cm}$ lub większym (Grzywacz, Pietrzak, 2013; Zarzyński, 2019). Siedem z najgrubszych okazów wyróżnia się obwodem pnia powyżej $1000 \mathrm{~cm}$ na wysokości $130 \mathrm{~cm}$ od powierzchni gruntu (Zarzyński, 2019).

Turystyka kulturowa i przyrodnicza rozwijają się i stopniowo zdobywają coraz więcej zwolenników. W czasach rosnącego zapotrzebowania człowieka na wypoczynek oraz wzrostu świadomości ekologicznej społeczeństwa nasila się tendencja do spędzania wolnego czasu na łonie natury, w otoczeniu krajobrazu wiejskiego, z dala od cywilizacji. Jednakże turyści są coraz bardziej wymagający i poszukują nowych doznań. Organizatorzy turystyki stoją zatem przed trudnym zadaniem: przygotowywane przez nich oferty muszą być coraz bardziej atrakcyjne i niepowtarzalne (Machnik, Kurczewski, 2014). Turystyka kulturowa to m.in. podróżowanie, którego podstawowym motywem jest dziedzictwo kulturowe, szerzej rozumiane również jako życie codzienne, nauka i technika oraz środowisko geograficzne, a także literatura poświęcona różnym regionom i kuchnia traktowana jak sztuka życia. Takie pojmowanie turystyki kulturowej pozwala wplatać w nią wątki przyrodnicze (Machnik, Kurczewski, 2014, za: Buczkowska, 2008). Z kolei o turystyce przyrodniczo-kulturowej mówi się wtedy, gdy poznaje się otoczenie przyrodnicze zaaranżowane i utrzymywane przez człowieka (np. założenia parkowe, ogrody botaniczne i zoologiczne itp.) lub zwiedza się obszary stanowiące dziedzictwo naturalne (rezerwaty, parki narodowe itp.). W podróży nadrzędnym celem jest poznanie naturalnych walorów środowiska. Krótkie (jednodniowe lub kilkugodzinne) wyprawy nie wymagają od uczestnika 
specjalnego przygotowania (z wyjątkiem tych do rezerwatów, parków narodowych i innych obszarów naturalnych), natomiast wskazane jest zainteresowanie problematyką. Mogą to być wycieczki do miejsc, w których zdobędzie się wiedzę z zakresu szeroko pojętego przyrodoznawstwa, a także (jak w przypadku palmiarni, arboretum, ogrodów botanicznych i zoologicznych) w których ma się dobrą sposobność do poznania fauny i flory egzotycznej bez konieczności odbywania dalekich podróży. Obie formy zakładają zainteresowanie problematyką prezentowaną podczas zwiedzania oraz zaangażowanie osób biorących w nim udział (Machnik, Karczewski, 2014). Wielu turystów nie jest ściśle nastawionych na poznawanie tylko przyrody czy kultury w miejscu wypoczynku, a jednocześnie zdecydowanie deklaruje potrzebę odejścia od turystyki masowej.

Pojęcie produktu turystycznego jest stosunkowo nowe w terminologii stosowanej w branży, gdyż specjaliści z tego zakresu używają go dopiero od kilkunastu lat. W literaturze turystycznej termin „produkt”, na który w dużym stopniu składają się usługi, budził początkowo sprzeciw językoznawców, uważających, że jest on zarezerwowany dla wytworów o charakterze materialnym (Kaczmarek, Stasiak, Włodarczyk, 2005). Tymczasem w turystyce przeważają usługi, które są nienamacalne, niemożliwe do sprawdzenia przed kupnem, czyli niespełniające kryteriów produktu materialnego.

Współcześnie produkt turystyczny określany jest jako połączenie materialnych dóbr i niematerialnych usług. Gołembski i in. (1998) definiują produkt turystyczny jako dobra i usługi nabywane przez turystę w całym cyklu związanym z podróżą (przed wyjazdem, w czasie podróży oraz $\mathrm{w}$ trakcie pobytu $\mathrm{w}$ miejscu recepcji). Na produkt turystyczny składają się atrakcje, infrastruktura turystyczna w miejscu docelowym oraz dostępność do nich (Middleton, 1996).

W przypadku turystyki przyrodniczej główną korzyścią może być bliski kontakt z przyroda, np. z ptakami, nawet jeśli jest to „bliskość przez lornetkę". Produkt rzeczywisty to odpowiednie (nieprzypadkowe) usługi, takie jak: zakwaterowanie nie w miejskim hotelu, ale w wiejskiej chacie, położonej w okolicy miejsca przebywania lub przelotu ptaków, wypożyczenie sprzętu (łodzi, ubioru, lornetki), korzystanie z czatowni, usługa przewodnika doprowadzającego w odpowiednie miejsca o właściwej porze oraz potrafiącego wyjaśnić zachowania ptaków. Niektórzy producenci dodają do zestawu usług coś specjalnego, o czym klient wcześniej nie był informowany, czyli oferują produkt wzbogacony. Może to być jakaś pamiątka, dodatkowa usługa, lepsze wyposażenie pokoju czy bezpłatny 
transport, zwiększające atrakcyjność pobytu (Pender, Sharpley, 2008). Zatem produkt turystyczny to „zintegrowany układ oczekiwań, korzyści i wrażeń, tworzących unikalną kompozycję trzech podróży: wyobrażonej, rzeczywistej i zapamiętanej" (Kaczmarek, Stasiak, Włodarczyk, 2002, s. 50).

Ze względu na przedmiot zainteresowania naukowego i edukacyjnego, wartość kulturalna, historyczną lub symboliczna, pojedyncze drzewa-pomniki przyrody lub ich skupienia - grupy lub aleje - są interesującymi obiektami dla turystów.

\section{Metodyka badań}

Celem artykułu jest określenie i scharakteryzowanie szeregu wartości przypisywanych drzewom, które uznawane są za wyjątkowe i mają szczególne walory turystyczne. Analizy przeprowadzono, opierając się na przeglądzie literatury oraz dostępnych informacji dotyczących pomnikowych drzew, a także na podstawie własnej bazy danych pomników przyrody, utworzonej z wykorzystaniem danych Generalnej Dyrekcji Ochrony Środowiska oraz Centralnego Rejestru Form Ochrony Przyrody w Polsce (2017). Opisano te cechy drzew uważanych za wyjątkowe, które mogą być wykorzystane $\mathrm{w}$ działaniach promocyjnych. W bazie wyróżniono okazy najcenniejsze pod względem przyrodniczym i społecznym, które nierzadko uwzględniane są w europejskich oraz krajowych zestawieniach najcenniejszych $w$ tym zakresie drzew. Ze względu na znaczenie zaproponowano, iż drzewa te mogą stanowić element wieloaspektowego, zwartego produktu turystycznego regionu.

\section{Wyniki}

Sędziwe drzewa pokaźnych rozmiarów to nie tylko ciekawe egzemplarze przyrodnicze, ale również obiekty kulturowe o dużym znaczeniu historycznym, pamiątkowym, patriotycznym, dydaktycznym i symbolicznym. Mogą one występować pojedynczo lub w skupiskach, jako grupa, aleja lub gaj (Kasprzak, 2011). Drzewa pomnikowe w lesie są raczej okazami pochodzenia naturalnego lub pozostałością starych puszcz. Z kolei w krajobrazie rolniczym rosną najczęściej na miedzach, przy drogach śródpolnych, wśród zadrzewień śródpolnych, w parkach podworskich i wśród zadrzewień przyzagrodowych. Drzewa rosnące przy zabudowaniach mają często znaczenie historyczne i symboliczne. 
Aleje-pomniki przyrody - na terenie miast, wzdłuż szlaków komunikacyjnych poza miastami (np. ścieżki, drogi polne), wzdłuż grobli lub jako pasy zadrzewień śródpolnych - powstały w wyniku celowych nasadzeń, $\mathrm{w}$ trakcie realizacji zaprojektowanych założeń urbanistycznych lub z powodu świadomego kształtowania krajobrazu dla potrzeb gospodarczych (Kasprzak, 2011).

Na terenie Polski istnieją bogate zasoby drzew pomnikowych i innych dendrologicznych osobliwości (Kusiak, Węgiel, Borkowski, Danielewicz, 2008), jednakże w większości nie są to okazy dobrze znane, nawet lokalnej społeczności.

Z punktu widzenia turystycznego ważne są walory drzewa, związane z jego znaczeniem przyrodniczym, społecznym i kulturowym:

- drzewa jako przedmiot zainteresowania naukowego i edukacyjnego (np. dąb Bartek z Zagnańska, dęby rogalińskie z Rogalina, dąb Łokietka z Laski, dąb Piotrowy z Toporowa);

- wartości estetyczne lub kulturowe drzew-pomników przyrody ze względu na wiek, wyjątkowo okazałe rozmiary, niespotykany pokrój i kształt (np. dąb Mieszko z Warszawy, topola z Leszna, platan Olbrzym z Chojny, lipa z Cielętnik i wiele innych);

- drzewa mające wartość kulturowa, historyczną lub symboliczna, rosnące w widocznym, dostępnym miejscu w krajobrazie (np. dąb Chrobry z Białobrzegów, dąb z Rudki, sosna Ośmiornica z Proszowa, dąb Uparty Mazur z Młocka);

- okazy związane ze sferą duchową (np. lipa z Czarnego Potoku i z Cielętnik);

- drzewa w końcowej fazie życia lub martwe, o szczególnej wartości historycznej lub symbolicznej (dąb Napoleon z Zaboru, topola z Leszna, lipa drobnolistna z Cielętnik, dąb Baublis z Borodzia na Litwie, jodła z Pszczelin, wiąz z Pawiaka w Warszawie, sosna Powstańców z Górek).

Drzewo może być samo w sobie wartością kulturowa, ale może też inspirować działalność kulturalną, oddziałując na wyobraźnię, która utrwala się w formie architektonicznej, rzeźbiarskiej, malarskiej, literackiej czy muzycznej. $Z$ analiz przeprowadzonych przez autorkę wynika, iż istnieją drzewa, które mają interesującą historię, wartą ukazania w regionalnych i lokalnych ulotkach, broszurach czy przewodnikach turystycznych, np. drzewa w zabytkowych założeniach podworskich. Takie okazy niewątpliwie składają się na przyrodnicze i kulturowe dziedzictwo kraju bądź regionu. Poznanie ich oraz związanych z nimi tradycji, a także zdarzeń uświadamia zaskakującą różnorodność kulturową i dziejową (Pietrzak, 
Zawadka, 2009). Walory te mogą być (i w niektórych przypadkach są) wykorzystywane w promocji turystycznej lokalnie bądź na szerszą skalę.

W dalszej części artykułu zostaną przedstawione przykłady drzew uznanych za pomniki przyrody, ukazane poprzez pryzmat ich walorów przyrodniczych i wartości kulturowych, mających znaczenie w turystyce wraz ze wskazaniem tych cech, które mogłyby stanowić część szerszego produktu turystycznego.

1. Drzewa rosnące w pobliżu obiektów turystyki kulturowej - przy zabytkach sakralnych, zamkach i pałacach, cmentarzach historycznych, muzeach, budowlach współczesnych. Drzewa pomnikowe występują bardzo często w zabytkowych założeniach parkowo-ogrodowych. W różnych stylach sztuki ogrodowo-parkowej, zwłaszcza w ogrodach romantycznych, za najpiękniejsze uważano drzewa stare, z reguły rosnące samotnie. Uznawano, że liczne dziuple i martwe konary upiększają drzewo i nie psują jego walorów dekoracyjnych. Znalazło to odbicie także w literaturze romantycznej, której twórcy zwracali uwagę na piękno i wielkość starych drzew, zwłaszcza dębów (Kasprzak, 2011). Pomnikowe drzewa nierzadko znajdują się w parkach podworskich i przypałacowych czy rosną w bezpośrednim sąsiedztwie obiektów kulturalnych.

Za cenne okazy uznaje się wspomniane trzy dęby rogalińskie (województwo wielkopolskie, gmina Rogalin). W okolicach Rogalina rośnie ok. 500 okazałych egzemplarzy tego gatunku, tworzących jedno z największych skupisk dębów w Europie. Rogalińskie dęby stanowiły atrakcję turystyczną już w drugiej połowie XIX w. Dzięki lokalizacji w pobliżu popularnego obiektu muzealnego cieszą się uznaniem turystów. Jeden z nich, Czech, jest już martwy, a dwa pozostałe - Lech i Rus, mają obwody przekraczające $650 \mathrm{~cm}$ na wysokości $130 \mathrm{~cm}$ od powierzchni gruntu. Rosną nieopodal pałacu, w interesującej scenerii naturalistycznego parku krajobrazowego.

Wydaje się, że człowiekowi od zawsze towarzyszy fascynacja ogromem i majestatem starych drzew - pozostałością prastarej puszczy. Dla Słowian i wielu innych ludów przedchrześcijańskiej Europy szczególnie okazałe dęby były święte. Ich odczuwalną obecność w otoczonych opieką gajach wplatano w barwną mitologię i powtarzany przez pokolenia religijny przekaz. Do tej tradycji nawiązuje legenda „O Lechu, Czechu i Rusie" - braciach, którzy przed wiekami dotarli do Rogalina i posadzili najsłynniejsze w Wielkopolsce, nazwane ich imionami trzy dęby. Trwanie tych drzew przez wieki poruszało wyobraźnię niejednego ludzkiego pokolenia. Dowodem ich silnego wpływu są obrazy artystów: M. Wywiórskiego - prezentowane w Galerii Rogalińskiej, oraz 
L. Wyczółkowskiego - eksponowane w muzeum w Bydgoszczy. Połączenie ciekawej historii drzew w kompozycji $z$ ich znaczeniem edukacyjnym i kulturowym stanowi interesującą ofertę dla zwiedzających pałac lub Muzeum Lasu w Rogalinie.

Kolejnym ciekawym okazem jest dąb Bażyńskiego z Kadyn (Regionalna Dyrekcja Lasów Państwowych w Gdańsku, Nadleśnictwo Elbląg). Jest to znany i często odwiedzany dębowy pomnik przyrody w północnej części kraju (Zarzyński, Tomusiak, 2014). Rośnie przy trasie nr 503, prowadzącej z Elbląga do Fromborka, po prawej stronie, przy wjeździe do miejscowości Kadyny. Drzewo jest wyeksponowane odpowiednią aranżacją otoczenia, dzięki czemu widać je z daleka. Jest to jeden z największych okazów tego gatunku rosnących w naszym kraju. Jego wymiary są imponujące: obwód na wysokości 1,3 m wynosi $1032 \mathrm{~cm}$, a wysokość $25 \mathrm{~m}$ (Grzywacz, 2007). Wiek drzewa, według tablicy informacyjnej, wynosi ok. 700 lat. Teren wokół pomnika przyrody jest dobrze przygotowany na przyjęcie turystów, znajdują się tam: niewielki parking, ławeczki oraz kosze na śmieci. Informacje na tablicy nawiązują do osoby J. Bażyńskiego (ok. 1390-1459), szlachcica pruskiego i właściciela Kadyn, przywódcy opozycji antykrzyżackiej oraz zwolennika wcielenia ziem zakonu krzyżackiego do Korony.

Drzewo było znane i stanowiło atrakcję przyrodniczą już w XIX w. A. Brinkner, jeden z ówczesnych właścicieli Kadyn, stwierdził doświadczalnie, że w dziupli pnia może pomieścić się 11 żołnierzy w pełnym rynsztunku bojowym. Wnętrze drzewa w czasach historycznych wykorzystywane było w dość nietypowy sposób - istnieje opowieść, że za panowania Prus w pniu znajdował się mały kantor (Zarzyński, Tomusiak, 2014), a w okresie przedwojennym - piwiarnia. Przy dębie rozpoczyna się ścieżka dydaktyczna dla zwiedzających rezerwat „Kadyński Las”, a w pobliżu rośnie kilka innych okazałych, choć znacznie mniejszych dębów.

Drzewa rosnące przy zabudowaniach często mają znaczenie historyczne i symboliczne. Podobne znaczenie mają niektóre okazy rosnące przy szlakach komunikacyjnych poza miastami (np. ścieżkach, drogach polnych), wzdłuż grobli lub jako pasy zadrzewień śródpolnych. Powstały w wyniku celowych nasadzeń lub z powodu świadomego kształtowania krajobrazu dla potrzeb gospodarczych, np. pomnikowa aleja drzew wzdłuż ul. Żwirki i Wigury w Warszawie.

Pomniki przyrody pełnią nie tylko funkcję estetyczną, ale też upamiętniają postaci i wydarzenia historyczne, utrwalają wspomnienia, podania i legendy. Potęgują one również emocje związane z pobytem w danym miejscu. 
Warto podać przykład dębu szypułkowego - pomnika przyrody rosnącego przy kościele w Birczy (powiat przemyski, województwo podkarpackie), o przyziemnym obwodzie $16 \mathrm{~m}$. Ten okaz zapewne rósł już w 1603 r., kiedy wznoszono obok modrzewiowy kościół, rozebrany w 1920 r. (Zarzyński, Tomusiak, 2014). Prawdopodobnie drzewo posadzono u wejścia do nieistniejącego już w tym miejscu cmentarza. Pozostaje ono żywym świadkiem wielu ważnych zdarzeń historycznych z kilku minionych wieków, a także dramatycznych zajść z przełomu lat 1945/1946 w związku z atakami Ukraińskiej Powstańczej Armii (Misiak, 2010). Innym przykładem $z$ tego samego regionu jest dąb szypułkowy z Rudki, jeden z najstarszych dębów w Polsce. Zapewne był już dojrzałym drzewem w 1693 r., kiedy stawiano obok niego oryginalną cerkiew typu bojkowskiego. Warto wspomnieć również o drzewach w parku Zamkowym w Przemyślu - grabie zrośniętym z brzoza, pod którymi wiele par wyznało sobie wzajemne uczucia; brzozę wycięto wiosną $2006 \mathrm{r}$. (Szwarc-Bronikowski, 2010). Ciekawy okaz miłorzębu dwuklapowego ze specjalnym podestem wokół pnia można spotkać w parku w Krasiczynie. Drzewo to budzi niemałe zainteresowanie zwiedzających, ponieważ wierzy się, że trzykrotne obejście go ma zapewnić szczęście. Na uwagę zasługują również grupy monumentalnych starych drzew na wzgórzach, tworzące często malownicze kulminacje perspektyw (np. Śmiełów, Wąsowo - województwo podkarpackie).

2. Drzewa rosnące przy szlakach turystycznych przebiegających przez region lub miejscowość. Na uwagę w tym przypadku zasługuje najbardziej znane drzewo w Polsce - dąb szypułkowy Bartek z Zagnańska (Regionalna Dyrekcja Lasów Państwowych w Radomiu, Nadleśnictwo Zagnańsk), upamiętniony w herbie gminy Zagnańsk. Łatwo do niego dotrzeć nawet bez samochodu, gdyż przez teren gminy częściowo wytyczone są dwie trasy rowerowe oraz przebiega pięć znakowanych pieszych szlaków turystycznych, z których jeden ZagnańskBliżyn kieruje do dębu Bartka. Turyści znają ten okaz, stanowiący typowy przykład drzewa pomnikowego, pomimo że nie jest ani najstarszy, ani największy w Polsce. Drzewo to było sławne już na początku XIX w. Dąb został objęty ochroną jako pomnik przyrody w 1954 r. Okaz imponuje pokrojem i rozmiarami - jego obwód wynosi $981 \mathrm{~cm}$, wysokość 29 m (Grzywacz, 2007). Stał się symbolem regionu kieleckiego, a także swojej miejscowości, obowiązkowym celem wycieczek szkolnych oraz turystycznych z całej Polski i nie tylko. Zdarzało się, że jednego dnia pod konarami sędziwego drzewa przewijało się od 80 do 100 zorganizowanych wycieczek, nie licząc indywidualnych osób i mniejszych grup 
(Zarzyński, Tomusiak, 2014). Obok Bartka posadzono wychodowany z jego żołędzi dąb Bartuś.

Ciekawe drzewa-pomniki przyrody z powyższej grupy można podziwiać na chojnowskim szlaku zabytków przyrody: (szlak czarny) Zalesie Górne - Dąb Stephana (1,6 km) - rezerwat „Uroczysko Stephana” (3,6 km) - rezerwat „Pilawski Grąd” (6,4km) - Chojnów - Pilawa $(8,0$ km) - rezerwat "Chojnów” (9,5 km).

Interesującą inicjatywą była również akcja podjęta w 2013 r. przez Narodowy Instytut Dziedzictwa i Generalnej Dyrekcji Ochrony Środowiska, pt. „Drzewa Sobieskiego. Na odsiecz dębom, lipom i innym drzewom”, dzięki której powstał szlak turystyczny „Szlakiem drzew Sobieskiego” (Generalna Dyrekcja Ochrony Środowiska, 2020). Celem akcji było odnalezienie drzew, związanych z odsieczą wiedeńską i postacią króla Sobieskiego, zasadzonych przez Polaków na cześć władcy po jego zwycięskiej bitwie pod Wiedniem. Tradycję sadzenia drzew najprawdopodobniej zapoczątkował sam król Jan III Sobieski, znany ze swoich zamiłowań przyrodniczych. Podczas marszu na Wiedeń, 23 sierpnia 1683 r., zasadził przed klasztorem Franciszkanów w Gliwicach dwie lipy, choć w legendach mowa nawet o 14. „Sieć” Drzew Sobieskiego tworzą m.in. (Generalna Dyrekcja Ochrony Środowiska, 2020; Narodowy Instytut Dziedzictwa, 2020):

- Jan i Marysieńka - dwie okazałe lipy, rosnące na obszarze Regionalnego Centrum Naukowo-Technologicznego w Podzamczu Chęcińskim, tuż za bramą triumfalną wzniesioną pod koniec XVII w. na cześć Jana III Sobieskiego;

- drzewa Sobieskiego z Konopisk - rosną przy ul. Lipowej w miejscowości Konopiska k. Częstochowy. Legenda głosi, że zostały posadzone w 1683 r. podczas marszu Jana III Sobieskiego na Wiedeń;

- dąb Sobieskiego - rośnie kilkadziesiąt metrów od pałacyku myśliwskiego przy czerwonym szlaku pieszym „Husarii Polskiej” i pieszym szlaku niebieskim w Rezerwacie „Łężczok”;

- lipa Sobieskiego - ma ponad 500 lat, obwód jej pnia wynosi 5,85 m; rośnie na najwyższym wzniesieniu Falkowej (ponad 400 m n.p.m.); prowadzi do niej niebieski szlak.

3. Drzewa-pomniki przyrody mogące stanowić kulturalnie znaczącą ofertę przyrodniczą, rosnące na terenie parków krajobrazowych czy leśnych kompleksów promocyjnych. Wiele drzew uznanych za pomniki przyrody to pozostałości starych puszcz czy borów, które przetrwały do naszych czasów. Ciekawym pod tym względem okazem jest dąb Zygmunt August - rosnący na terenie Rezerwatu przyrody "Zagożdżon" w Kozienickim Parku Krajobrazowym, niedaleko wsi Przejazd. 
Wiek dębu oszacowano na 230-350 lat, jego pień ma $530 \mathrm{~cm}$ obwodu, pierścienica $102 \mathrm{~cm}$, a wysokość drzewa to 28 metrów (Instytut na rzecz Ekorozwoju, 2020). Cechą charakterystyczną drzewa jest jego strzelisty pień. Swoją nazwę zawdzięcza królowi Zygmuntowi II Augustowi, który w XVI w. znacznie przyczynił się do rozwoju pobliskich Kozienic (Wrota Mazowsza, 2020).

Przykładem drzew-pomników przyrody mogących stanowić kulturalnie znaczącą ofertę przyrodniczą jest Szlak Dębów Królewskich, który znajduje się nieco na północny zachód od Białowieży (województwo podlaskie), pomiędzy wioskami Pogorzelce i Teremiski, przy stacji wąskotorówki i żółtym szlaku pieszym Białowieża-Narewka. W pobliżu Białowieży wytyczono ścieżkę edukacyjną o długości ok. 500 m, wśród kilkudziesięciu dębów w wieku od 150 do 500 lat. Te wspaniałe okazy starodrzewu w uroczysku Stara Białowieża noszą imiona władców Polski oraz Litwy, którzy kiedyś spotykali się w Puszczy Białowieskiej na polowaniach. Wędrując tym szlakiem, poznaje się historię Puszczy Białowieskiej, Polski oraz Litwy od XII do XVIII wieku. Przy ścieżce umieszczono tabliczki z nazwami drzew, ich wiekiem i rozmiarami oraz z krótką informacją o władcy, którego imię nadano danemu drzewu. Przykładowe nazwy dębów, które można spotkać na szlaku to: Witold, Trojden, Giedymin, Leszek Biały, Kazimierz Wielki, Bona Sforza, Władysław Jagiełło, Stefan Batory, Zygmunt August, Jan Kazimierz czy Barbara Radziwiłłówna (Atrakcje Podlasia, 2020). Ścieżka powstała w 1978 r., ale w 2008 r. została zmodernizowana, przystosowana do potrzeb osób niepełnosprawnych oraz wzbogacona o tablice informacyjne. Turysta, spacerując po szlaku, nie tylko może odpoczać na świeżym powietrzu, ale również wzbogacić wiedzę historyczną.

4. Drzewa związane z kultem religijnym, sferą duchową. Wiele drzew zabytkowych ma w pewnym sensie znaczenie kultowe, bowiem zawieszano na nich bądź stawiano w ich sąsiedztwie kapliczki, które są odwiedzane przez okoliczną ludność. Warto zwrócić uwagę, że przy świątyniach można spotkać wiele drzew oznaczonych zieloną tabliczką z napisem „Pomnik przyrody”.

Wśród takich okazów są m.in.: zabytkowa lipa przy kościele pw. św. Apolonii w Cielętnikach (województwo śląskie), dąb szypułkowy z Rudki (gmina Sieniawa, powiat przeworski, województwo podkarpackie), dąb Poganin z Węglówki (gmina Korczyna, powiat krośnieński, województwo podkarpackie), lipy drobnolistne przy kościele pw. św. św. Apostołów Piotra i Pawła w Tyliczu (gmina Krynica-Zdrój, powiat nowosądecki, województwo małopolskie). 
Z przekazów legendarnych lub historycznych wynika, iż na drzewach dokonywały się objawienia Matki Bożej (potwierdzane lub nieuznawane oficjalnie przez władze kościelne), a okazy takie stawały się później miejscami kultu maryjnego (tab. 1). Niektóre z nich zostały objęte ochroną prawną (Grzywacz, 2006).

Tabela 1. Gatunki drzew, na których objawiała się Matka Boża - wybrane przykłady

\begin{tabular}{|l|l|}
\hline \multicolumn{1}{|c|}{ Gatunek drzewa } & \multicolumn{1}{|c|}{ Objawienia } \\
\hline Lipa & $\begin{array}{l}\text { Matka Boża Świętolipska (Święta Lipka), Matka Boża } \\
\text { Lipska z Lubawy, Matka Boża Ostrożańska (Ostrożany) }\end{array}$ \\
\hline \multirow{2}{*}{ Dąb } & $\begin{array}{l}\text { Matka Boża Kochowińska (Żydaczów k. Stryja), Matka } \\
\text { Boża Królowa Pokoju (Stoczek Warmiński), Bolesna Pani } \\
\text { Hałcnowska (Bielsko-Biała) }\end{array}$ \\
\hline \multirow{2}{*}{$\begin{array}{l}\text { Drzewa } \\
\text { bez nazwy gatunku }\end{array}$} & $\begin{array}{l}\text { Leżajska Matka Boża Pocieszenia, Królowa Mazowsza } \\
\text { i Pani Skępska, Matka Boża Gidelska, Krasnobrodzka } \\
\text { Szafarka Łask - Pocieszycielka Zamojszczyzny, Matka Boża } \\
\text { Pocieszenia z Jodłówki, Matka Boża Studzieniczna (Prze- } \\
\text { więź, Augustów) }\end{array}$ \\
\hline
\end{tabular}

Źródło: opracowanie na podstawie Grzywacz (2006).

Interesującym przykładem związanym ze sferą duchową jest pomnik przyrody Pięć Sosen - pięć drzew wyrasta z jednego pnia - w miejscowości Wielkie Oczy (województwo podkarpackie). Według ludowych przekazów w XVIII w. dzieciom, które pasły w tych okolicach bydło, ukazała się Matka Boża. W miejscu tym wybudowano kaplicę i umieszczono w niej obraz Matki Bożej Nieustającej Pomocy. Między rozgałęzieniami sosny wytrysło źródło, którego woda miała właściwości uzdrawiające. Miejsce to stało się destynacją pielgrzymek wiernych. W 1944 r. kaplica została zburzona przez żołnierzy Armii Czerwonej, a obraz zaginął. W 1973 r. J. Kuchta, mieszkaniec Skolina, postawił tam drewnianą kapliczkę z wizerunkiem Matki Bożej Pacławskiej, jednak spłonęła ona w październiku 2006 r. Poświęcenie nowej nastąpiło w maju 2007 r. Jest to też miejsce, w którym spotykają się myśliwi w dniu imienin swojego patrona - św. Huberta (Marszałek, 2010).

Na uwagę zasługuje również sosna z dużą dziupla, kryjącą w sobie kapliczkę z rzeźbą Chrystusa Ukrzyżowanego w Heluszu (województwo podkarpackie). Ze „Świętą Dziuplą" przetrwała lata wojny i okupacji, a przed zniszczeniem przez sowieckich żołnierzy uchroniła ją petycja mieszkańców do dowódcy wojskowego oddziału (Marszałek, 2010). 


\section{Podsumowanie}

W niniejszym artykule przedstawiono przykłady drzew-pomników przyrody jako interesujące obiekty kulturowe. Pomniki przyrody mają nie tylko duże znaczenie dla nauki, ale wpływają także na ocenę estetyki krajobrazu, zwiększając jego różnorodność i atrakcyjność, np. pod kątem aktywności turystyczno-rekreacyjnej. Często są one związane z określonymi wydarzeniami historycznymi lub wybitnymi postaciami naszej kultury narodowej. Drzewa jako pomniki przyrody wyraźnie wpisują się w turystykę kulturową. Poprzez nazwy własne bezpośrednio nawiązują do legend i podań, faktów historycznych, upamiętniają ludzi zasłużonych dla regionu czy nauki, a ze względu na wiek przypominają minione epoki. Stanowią element wyraźnych kompozycji krajobrazowych, parkowych i ogrodowych, sakralnych, ale także miejskich (np. aleja Niepodległości w Poznaniu). Utrwalają w pamięci zdarzenia religijne lub postacie świętych, często legendarnie, ale bardzo skutecznie (np. drzewa na placu św. Wojciecha w Gnieźnie).

Jednakże popularność pomnikowych drzew jako obiektów turystycznych jest zróżnicowana. Niektóre z nich, bardzo często odwiedzane, jak słynny dąb Bartek z Zagnańska, dąb Napoleon z Zagórza czy wiąz z Komorowa, stały się niemal ikoną turystyki. Inne znane są jedynie lokalnej społeczności lub wąskiemu gronu pasjonatów.

Ze względu na znaczenie, okazy popularne w społeczeństwie mogą stanowić $z w$. punktowy produkt turystyczny lub być elementem szerszego produktu turystycznego. Uzupełnieniem oferty mogą być mało znane drzewa-pomniki przyrody, ale mające znaczenie lokalne czy regionalne ze względu na wartości przyrodnicze, jak również na związane z nimi legendy i historie.

Aby okazy te tworzyły element produktu turystycznego - np. miejsca lub szlaku prezentującego dziedzictwo przyrodnicze lub kulturowe (czy historyczne) regionu - pozostałe elementy powinny być powiązane nadrzędną idea, np. edukacyjną. Szlak może być zaprojektowany jako ścieżka piesza albo samochodowa, składająca się z różnorodnej infrastruktury turystycznej, zlokalizowanej wzdłuż trasy. Przykładem takiego działania, uwzględniającego okazy drzew-pomników przyrody, może być europejska sieć dróg rowerowych EuroVelo, Szlak Orlich Gniazd (województwo małopolskie) czy Szlak Drzew Sobieskiego.

W literaturze podkreśla się wyjątkowość i niepowtarzalność produktu turystycznego. Drzewa-pomniki przyrody, zwłaszcza z grupy drzew najbardziej znanych społeczeństwu, niewątpliwie stanowią ciekawe okazy 
dla szerokiego grona odbiorców, jak również są obiektami unikatowymi. Elementy przyrodnicze, takie jak obszary chronione czy kulturalne, np. zabytki historyczne, wraz z drzewami-pomnikami przyrody mogłyby się wzajemnie dopełnić w kreacji złożonego produktu turystycznego.

Reasumując, należy stwierdzić, że pojedyncze egzemplarze drzew uznanych za pomniki przyrody mogą okazać się walorem o niewystarczającej sile przyciągania turystów. Wobec tego powinny być one uwzględniane jako jeden ze składników bardziej rozbudowanego produktu turystycznego.

\section{Bibliografia}

Atrakcje Podlasia (2020). Pobrane z: www.atrakcjepodlasia.pl (06.03.2020).

Borkowski, K., Danielewicz, W., Kusiak, W., Węgiel, A. (2008). Najgrubsze drzewa Lasów Państwowych. Warszawa: Centrum Informacyjne Lasów Państwowych.

Generalna Dyrekcja Ochrony Środowiska (2020). Pobrane z: www.gdos.gov.pl (06.03.2020). Gołembski, G. (1998). Przedsiębiorstwo turystyczne w gospodarce wolnorynkowej. Poznań: Akademia Ekonomiczna w Poznaniu.

Grzywacz, A. (2006). Problematyka przyrodniczo-leśna w konkordancji biblijnej. W: A. Grzywacz, Kulturotwórcza rola lasu i leśnictwa (s. 95-103). Lublin: Polskie Towarzystwo Leśne.

Grzywacz, A. (2011). Drzewa jako obiekty kulturowe. Studia i Materiały CEPL w Rogowie, $13(4 / 29), 45-62$.

Grzywacz, A., Pietrzak, J. (2013). Drzewa - pomniki przyrody. Warszawa: Polskie Towarzystwo Leśne.

Grzywacz, M. (2007). Stan zdrowotny oraz ocena wartości społecznej i historycznej najstarszych i najgrubszych dębów szyputkowych w Polsce. Praca magisterska (maszynopis). Warszawa: Wydział Leśny, Szkoła Główna Gospodarstwa Wiejskiego.

Instytut na rzecz Ekorozwoju (2020). Pobrane z: www.ine.eko.org.pl (6.03.2020).

Kaczmarek, J., Stasiak, A., Włodarczyk, B. (2002). Produkt turystyczny. Turystyka i Hotelarstwo, 1, 33-54.

Kaczmarek, J., Stasiak, A., Włodarczyk, B. (2005). Produkt turystyczny. Pomysł. Organizacja. Zarzadzanie. Warszawa: Polskie Wydawnictwo Ekonomiczne.

Kasprzak, K. (2005). Ochrona pomników przyrody. Zasady postępowania administracyjnego. Poznań: Wydawnictwo ABRYS.

Kasprzak, K. (2011). Drzewa - pomniki przyrody i pamiątki kultury. Turystyka Kulturowa, 4, 27-35.

Machnik, A., Kurczewski, R. (2014). Dziedzictwo przyrodnicze w rozwoju turystyki kulturowej na terenach wiejskich. Turystyka Kulturowa, 7, 34-48.

Marszałek, E. (2010). Leśne ślady wiary. Krosno: Wydawnictwo Ruthenus.

Michałowski, A. (1991). Drzewa w krajobrazie kulturowym. Studia i materiały. Zarzadu Ochrony i Konserwacji Zespołów Pałacowo-Ogrodowych. Warszawa: Zarząd Ochrony i Konserwacji Zespołów Pałacowo-Ogrodowych.

Middleton, V.T.C. (1996). Marketing w turystyce. Warszawa: PAPT.

Misiak, T. (2010). Magiczne drzewa w dziejach, legendach i środowisku nad środkowym Sanem. Rzeszów: Podkarpacki Instytut Książki i Marketingu.

Narodowy Instytut Dziedzictwa (2020). Pobrane z: www.nid.pl (08.03.2020). 
Ochrona Środowiska 2018 (2018). Warszawa: Główny Urząd Statystyczny.

Pender, L., Sharpley, R. (red.) (2008). Zarzadzanie turystyka. Warszawa: Polskie Wydawnictwo Ekonomiczne.

Pietrzak, J. (2011). Metodyka i kryteria uznawania za pomniki przyrody drzew oraz określania ich klas wartości przyrodniczej i społecznej. Rozprawa doktorska (maszynopis). Warszawa: Wydział Leśny, Szkoła Główna Gospodarstwa Wiejskiego.

Pietrzak, J., Zawadka, J. (2009). Wykorzystanie turystyczne drzew pomnikowych na terenie Lasów Państwowych. Studia i Materiały CEPL, 11 (4/23), 158-164.

Rozporzadzenie Ministra Środowiska z dnia 4 grudnia 2017 r. w sprawie kryteriów uznawania tworów przyrody żywej i nieożywionej za pomniki przyrody. Dz.U. 2017, poz. 2300.

Szwarc-Bronikowski, S. (2010). Świadkowie naszych dziejów. Warszawa: Wydawnictwo Prószyński i S-ka.

Szczepanowska, H.B. (2007). Ekologiczne, społeczne i ekonomiczne korzyści z drzew na terenach zurbanizowanych. Człowiek i Środowisko, 31 (3-4), 5-26.

Ustawa o ochronie przyrody z dnia 7 kwietnia 1949 r. Dz.U. 1949, nr 25, poz. 180.

Ustawa o ochronie przyrody z dnia 16 kwietnia 2004 r. Dz.U. 2004, nr 92, poz. 880 ze zm.

Wagner, J. (2003). Trees - positive effect for human behavior. Arborist News, 12 (1), 23-24.

Wrota Mazowsza (2020). Pobrane z: www.wrotamazowsza.pl (06.03.2020).

Zarzyński, P. (2019). Liczba pomników przyrody i drzew pomnikowych w Polsce na podstawie inwentaryzacji Generalnej Dyrekcji Ochrony Środowiska z lat 2014-2015, Sylwan, 163 (3), 248-257.

Zarzyński, P., Tomusiak, R. (2014). 90 drzew. Okazy niezwykłe. Warszawa: Centrum Informacyjne Lasów Państwowych.

\title{
DRZEWA-POMNIKI PRZYRODY JAKO ELEMENT PRODUKTU TURYSTYKI KULTUROWEJ
}

\begin{abstract}
Abstrakt: W artykule poruszono problematykę wykorzystania walorów drzew, uznanych za pomniki przyrody w turystyce, które ponadto stanowią cenne pamiątki kultury i odgrywają istotną rolę $\mathrm{w}$ rozwijaniu i propagowaniu turystyki kulturowej. W opracowaniu zaprezentowano cenne przyrodniczo i kulturowo okazy drzew na potrzeby wykorzystania ich w ofercie turystycznej. Określono również, w jaki sposób drzewa-pomniki przyrody moga posłużyć do tworzenia rozbudowanego kulturowego produktu turystycznego.
\end{abstract}

Słowa kluczowe: drzewo-pomnik przyrody, ochrona pomników przyrody, wartość kulturowa drzew, turystyka kulturowa.

\section{TREES AS MONUMENTS OF NATURE: A PART OF CULTURAL TOURISM}

Abstract: The article deals with the value of trees considered as natural monuments in tourism. In addition to their natural value, they are cultural monuments and play an important role in the development and promotion of cultural tourism. Particularly valuable in terms of nature and culture are individual trees presented as a part of a tourist offer, often located in the vicinity of cultural tourism facilities. Furthermore, the possibility of using such trees as a way of expanding a cultural tourist product was outlined.

Keywords: trees as a natural monument, protection of natural monuments, cultural value of trees, cultural tourism. 